\title{
Textual Pasts and Futures
}

\section{The Southern Pseudepigrapha: An Overview}

This chapter, necessarily programmatic, seeks to accomplish several aims at once. It presents, in the first place, an argument for a hitherto unstudied transformation in the literary history of medieval South India, which saw the creation, promulgation, and reception of a set of interrelated corpora of anonymous texts composed in Sanskrit. The individual texts in these corpora were variously identified as tantras and purānas, earlier genre descriptors to which we will turn in a moment. What was distinctive of these new Southern tantras and purānas is that they evinced a specific concern with relating themselves to a range of antecedent texts and in incorporating and synthesizing earlier texts as source-material. In this, I claim, they embodied a new set of philological methods and concerns of their anonymous authors. These works in turn supplied the conditions of possibility for the works treated in the remainder of this book. The intellectual transformation which these earlier, pseudonymously authored texts embody produced a new mode of philology in its own right, and in turn catalyzed further conceptual and practical changes for the making of texts.

Much of my evidence for the dating and location as well as the significance of these texts I owe to recent scholarship. In what follows, I review some of these contributions; in addition, I provide two brief examinations of exemplary texts of each genre taxon, puranna and tantra. On the basis of these, I suggest that there was a set of shared techniques-what I call a philological 'toolkit' whose application is distinctive of the larger body of these Sanskrit texts. This set of techniques has not been previously recognized as 'philological', and indeed they do represent a mode of philology that is highly eccentric from the perspective of modern scholarship. Yet both their pervasion throughout these corpora (and well beyond) as well as the creativity of their application suggest that these techniques need to be taken seriously, and understood on their own terms. That this set of philological techniques provoked or otherwise interacted with the wider habits of text-making can be seen in the parallel innovations in a major piece of Tamil religious literature. This latter work, the Perriyapurānamam of the mid-twelfth century poet Cekkilār, shared a genre taxon with certain examples of the new anonymous philology but possessed a very different literary genealogy and embodied a different set of aesthetic and

(C) WHITNEY COX, 2017 | DOI: 10.1163/9789004332331_003

This is an open access article distributed under the terms of the Creative Commons 
practical priorities. That it nevertheless possessed recognizable connections with the mode of philology suggests just how systemic the transformation in fact proved to be.

To begin, an assertion. The far South — by which I mean essentially the Tamil country-from roughly the late eleventh century witnessed the creation of several new large corpora of pseudonymous literature, written within genre confines that were themselves already centuries old. Chief among these were the theological, liturgical, and speculative works that attached themselves to the disciplinary orders venerating the deities Viṣnu and Śiva, texts variously described as tantras, ägamas, saṃhitās, jñānas or bhedas; for convenience's sake, I will refer to these as either tantras or scriptures or scriptural works. All of these texts participate in the convention that they record the conversations of various mythic and supernatural figures, ranging from sages or demigods up to the great cosmic overlords and their families, conversations which are usually set down in simple versified Sanskrit. Similar in their narrative selfpresentation, a further class of newly created or redacted verse texts identified themselves with the hoary genre of purāna, 'lore' or 'work about the past.' Though overlapping to some degree with the contents of the tantras, these were at once more diverse in their matter and more discursive in their style.

I should emphasize that these two genres were extremely productive: large numbers of works styling themselves both tantras and purānas had been produced and read for centuries in every corner of the world in which Sanskrit was the privileged medium of elite literacy. Purāna as a genre likely dates back to the very beginning of the Common Era; the earliest surviving Śaiva tantra, the recently published Niśvāsatattvasamnhitā, was perhaps completed at some point prior to its eighth century. ${ }^{1}$ I take it to be axiomatic that all such texts claiming themselves to be transcriptions of supernatural conversations are in fact the compositions of human authors, and I presume that any reader would share in this conviction. So too did some literati in Indian premodernity, at least in a qualified way. This can be seen in the work of the influential philosopher Jayanta Bhatța (Kashmir, ca. $890 \mathrm{CE}$ ). In the course of his argument for the conditional validity of all varieties of religious revelation, insofar as they, like the Veda, are the work of God, Jayanta introduces an imagined objection: "But if

1 For the purānas, refer to Ludo Rocher, The Purāṇas. The History of Indian Literature vol. 2, fasc. 3. (Weisbaden: Harrassowitz, 1986); for the Niśvāsa, see Alexis Sanderson "The Lākulas: new evidence of a system intermediate between Pāñcārthika Pāśupatism and Āgamic Śaivism," The Indian Philosophical Annual 24 (2006), 152 ff. and now Dominic Goodall et al., eds. and trans., The Niśvāsatattvasaṃhitā: The Earliest Surviving Śaiva Tantra. v. 1 (Pondichéry: Institut Français de Pondichéry et al. 2015). 
we grant that the validity of all scriptures can be argued for in this way, then if I myself compose a scripture right now, it might come to be seen as valid in just a couple of days." As is often the case, the words of the imagined opponent are very much to the point: Jayanta has a particular example in mind, that of the Nilāmbaras ("Black-cloaks"), a self-styled orgiastic religious order put down in his lifetime by king Śankkaravarman (r. 883-902). ${ }^{2}$ Jayanta's criteria for identifying such confected scriptures — even if they are found in apparently old manuscripts - are telling: only works that had gained wide acceptance among learned people, which were not evidently in the self-interest of their propagators, and which conform to social propriety were actually divine utterances; ${ }^{3}$ other texts could be safely consigned to inauthenticity. In imposing a set of extrinsic criteria, above all his deference to the situational ethics of social utility and a learned appeal to the sensus communis, Jayanta's argument is typical of the received opinion of other classical and medieval thinkers.

These kinds of pseudonymous verse texts had been composed for many centuries prior to the eleventh, and had circulated far beyond South India; indeed, these were among the most wide-ranging works of the Sanskrit cosmopolis. ${ }^{4}$ And much of Sanskrit literature is pseudonymous in exactly this way: the epics, Manu's law code, and the Nätyaśästra, Sanskrit's founding treatise on dramaturgy and literary theory, are only a few of the works framed as conversations between various supernatural or otherwise fictitious speakers. This being the case, as well as the huge quantum of texts similar in their genre, whose authors assiduously sought to obliterate all trace of their actual origins in time and space, ${ }^{5}$ the claim to be able to locate specific works-still more the enormous creation of such works-in the far South from the late eleventh century stands in need of justification.

2 Nyāyamañjarī, 648: sarvāgamapramānatve nanv evam upapadite | aham apy adya yat kiñcid ägamaṃ racayāmi cet || tasyāpi hi pramānatvam dinaih katipayair bhavet |. On the Nīlāmbaras, see especially Csaba Desző, “'Much Ado about Religion': A Critical Edition and Annotated Translation of the Âgamaḍambara" (PhD, Balliol College, Oxford, 2006), viii-ix and the references cited there.

3 Nyāyamañjarī, 648: yeșāmnna mūlaṃ lobhādiyebhyo nodvijatejanah| teșām eva pramānatvam ägamānām iheșyate \|

4 For example, see the abundant documentation given in Alexis Sanderson "The Śaiva Religion among the Khmer, Part 1" Bulletin de l'Ecole française d'Extrême-Orient, 91 (2004) on the transmission of Śaiva literature and practice to Cambodia.

5 Cf. Sheldon Pollock, "Mīmāṃsā and the Problem of History in Traditional India," Journal of the American Oriental Society 109 no. 4 (1989), 610: "When the dominant hermeneutic of the Vedas eliminated the possibility of historical referentiality, any text seeking recognition of its truth claims ... was required to exclude precisely this referential sphere." 
Here I am especially indebted to the ongoing work a number of Indological colleagues, especially that of Alexis Sanderson and Dominic Goodall. These scholars have done and continue to do revolutionary work in the textual history of Śaiva and increasingly Vaiṣnava scriptural literature; their own philological project - while not ignoring the kind of developments of interest here-has been concerned with clarifying the contents of the early corpus of these traditions, removing by a convincing set of criteria later works or later excrescences to earlier works, and establishing relationships of dependence and filiation between texts into a well-wrought relative and increasingly absolute chronology. In Sanderson's magisterial accounts of the history of the Śaiva religion, the earliest testimony for the existence of Śaiva scriptures dates from the fifth century of the common era, with the canon proliferating over the following centuries into a complex set of interrelated textual corpora providing detailed instructions for the worship of Siva, his fierce aspect Bhairava, and any of several goddesses conceived as the deity's indwelling power (śakti). ${ }^{6}$ This corpus of religious texts was to provide the standard for élite ritual and speculation far beyond the confines of worshippers of the Śaiva pantheon, as it would provide the model and much of the linguistic raw material for similar scriptural canons created by worshippers of Viṣnu, as well by Buddhists, whose Vajrayāna (i.e. 'tantric' Buddhist) tradition is largely a repurposing and extension of the Śaiva prototype. ${ }^{7}$

This latter argument will not concern us here, but the parallel Vaiṣnava incorporation and adaptation of Śaiva texts was largely an affair of the South: it was there that the tradition of Vaiṣnava worship calling itself the Pañcarātra was the recipient of its tantric liturgical corpus. The Pañcarātra is an ancient tradition of the worship of Viṣnu, the earliest traces of which can be seen in

6 See Alexis Sanderson, "The Śaiva Age: The Rise and Dominance of Śaivism during the Early Medieval Period," in Genesis and Development of Tantrism, ed. Shingo Einoo (Tokyo: Institute of Oriental Culture, 2009), 45-53: this is the most recent and authoritative synthesis of his closely argued scholarly oeuvre. For earlier surveys of the evidence, see Sanderson, "Śaivism and the Tantric Traditions," in The World's Religions, ed. Stewart Sutherland (Boston: G.K. Hall, 1988) (more accessible) and "History through Textual Criticism in the study of Śaivism, the Pañcarātra and the Buddhist Yoginītantras," in Les Sources et le temps, ed. François Grimal (Pondicherry: Institut Français de Pondichéry, 2001) (more specialist).

7 See the initial demonstrations of this thesis in Sanderson, "Vajrayāna: Origin and Function," in Buddhism into the Year 2000 (Bangkok and Los Angeles: Dhammakāya Foundation, 1995) and "History through Textual Criticism", 41-47; this is elaborately defended (and much new evidence introduced) in "The Śaiva Age", 124-243. For a measured Buddhological response in what has become an increasingly tribalized debate, see Christian Wedemeyer, Making Sense of Tantric Buddhism (New York: Columbia University Press, 2012), 154-168. 
the epic Mahābhärata (especially the Nārāyanīyaparvan contained in its enormous Śäntiparvan), and which possessed a centuries-long connection with the brahmanical school of Vedānta, dating from at least to the time of the great nondualist thinker Śankkarācārya (fl. ca. $700 \mathrm{CE}$ ). ${ }^{8}$ The production of a new body of Pañcarātra injunctive and speculative scriptures was a process that had evidently begun in Kashmir, only to have these newly composed works transmit, along with so much else, into the peninsula. ${ }^{9}$ In the far South, this process of new scriptural creation continued: these works served as a vector for the wholesale integration of the liturgical, theological, and speculative systems that were the work of Kashmirian scholars - most of them Śaiva - that are dateable to the close of the 1ooos at the earliest. ${ }^{10}$ This pattern of demonstrable borrowing thus supplies one of the most reliable data for an external chronology of this process. Above all else, however, these new Southern compositions were concerned with regulating public worship in temples consecrated to Viṣnu, in a marked shift from the religion of individual salvation evident in the earlier Pañcarātra scriptures.

In this turn to prescribing the temple worship of their chosen deities, the authors of these southern Vaișnava pseudepigrapha were working in parallel with their Śaiva counterparts, and it is on this literature that recent scholarship has made conspicuous advances. An older scholarly consensus saw the Śaivasiddhānta - the liturgical and doctrinal middle ground of the religionas essentially a local Tamil subculture. This has now been replaced by an understanding of the school as a pan-Indic phenomenon, which underwent an epochal process of domestication in the far South. ${ }^{11}$ The transmission of the vast body of Śaiva scriptural, exegetical and philosophical material from Kashmir to the Tamil country seems to have occurred at the same time as it did for the Pañcarātra, as did the quite rapid creation of a corpus of new tantras incorporating and synthesizing the doctrinal developments of the Kashmiri-

8 For the Nārāyañȳya, see the essays collected in Peter Schreiner, ed., Nārāyaṇīya-Studien (Wiesbaden: Harrassowitz, 1997); the often-debated date for the lifetime of Sankara follows that given in Allen Thrasher, "The Dates of Mạ̣ḍana Miśra and Śạkara," Weiner Zeitschrift für die Kunde Südasiens 23 (1979).

9 See Sanderson, "The Śaiva Age", 61-70.

10 This last feature, which can be seen in the Pāñcarātrika Lakṣmītantra and Ahirbudhnyasamphitā's adaptation of the work of the Śaiva Kṣemarāja has been demonstrated by Sanderson ("History Through Textual Criticism", 35-38).

11 See the frequently acerbic review of older (and to some extent contemporary) scholarship in Dominic Goodall, The Parākhyatantra: A Scripture of the Śaivasiddhānta (Pondichéry: Institut Français de Pondichéry, 2004), xiii-xxxiv. 
ans. These new compositions supplied liturgies that were to be incorporated into the already flourishing temple culture of the far south, especially that of the Cola heartland in the Kaveri river delta.

Here, Goodall's work is decisive. In an effort to distinguish the earlier, panIndian Śaiva works, particularly of the Śaivasiddhānta, from later Southern compositions, he has articulated a set of criteria (early manuscripts in Kashmir and Nepal; citations and commentaries by scholars up to and including the twelfth century southerner Aghoraśiva) by which the early tantric sources may be distinguished. ${ }^{12}$ In light of these criteria, much of what now passes as the scriptural canon of the southern Siddhānta can be shown to be strictly local creations. Goodall has also adduced convincing evidence for the chronological limit to the creation of much of this canon: noting the wide range of later scriptural works quoted by the commentary on Jñānaśiva's mid-twelfth century Śivapüjästava, the author of which declares himself to be the greatgreat-grandson of Jñānaśiva's pupil Trilocana, Goodall is led to conclude that ca. $1350 \mathrm{CE}$ provides "a rough terminus ante quem" for the composition of a great many of these Śaiva works. ${ }^{13}$ Though representing a different tradition to that of the Śaivasiddhānta, the southern temple-tantra calling itself the Brahmay $\bar{a}$ mala can be taken to provide a corresponding rough a quo limit, as it correlates closely with the epigraphic testimony found in a temple of a local goddess now known as Kolaramma (in modern Kolar, Karnataka), dated to 1072-1073. This three-century window marks the limits of a reasonably precise periodization. ${ }^{14}$

Notably, while not all of the works thus judged to be more recent are concerned with temple worship, all of the works that do center on the temple are to

12 See especially Dominic Goodall, Bhatțarāmakaṇthaviracitā kiraṇavrttịh: Bhatța Rāmakanțha's commentary on the Kiranatantra (Pondichéry: Institut Français de Pondichéry, 1998), xl ff and The Parākhyatantra, xxii-xxv.

13 Dominic Goodall, "Problems of Name and Lineage: Relationships between South Indian authors of the Śaiva Siddhānta," Journal of the Royal Asiatic Society 10, no. 2 (2000): 212.

14 See Sanderson, "Atharvavedins in Tantric Territory," in The Atharvaveda and its Paippaläda Śäkhā: Historical and Philological papers on a Vedic Tradition, edited by Arlo Griffiths and Annette Schmiedchen (Aachen: Shaker Verlag, 2007), 277-278nn.; this text is to be distinguished from the work of the same name studied in Hatley's admirable doctoral thesis (Shaman Hatley, "The Brahmayāmalatantra and the Early Śaiva Cult of Yoginīs" (PhD. dissertation, University of Pennsylvania, 2007); see esp. 4-5). The relationship between this tantra and the liturgical, social and political surround of Kolar's temple culture provide an important part of the evidence for a reinterpretation of the early reign of the Cola king in whose early regnal years the inscriptions are dated: this is detailed in Whitney Cox, Politics, Kingship, and Poetry in Medieval South India: Moonset on Sunrise Mountain (Cambridge: Cambridge UP, 2016), 106-111. 
be found in this later stratum. This suggests a radical change in the sociology of their reception and reproduction. The earlier composers and consumers of the tantras seem to have been an élite audience of initiates, practicing a demanding religious discipline of private ritual and yoga, who embedded this regime in an evolving theological framework. By contrast, the new tantras regulating temple practice reached out to a wider constituency, inclusive of the priests who actually performed the work in the burgeoning Śaiva and Vaiṣnava temple complexes of the Cola period and after..$^{15}$ It was these less élite social actors from whose ranks we may presume these works' anonymous authors to have arisen.

Many of the new Śaiva tantras, like the Brahmayāmala just mentioned, bore the titles of earlier works, adopted from the lists of scriptures found in the works that had transmitted to the south. For Aghoraśiva, the deeply conservative scholiast whose career marks for Goodall the effective end of the 'classical' theology of the Śaivasiddhānta, this new proliferation of scriptural authorities may have been a source of intellectual discomfort, even embarrassment. For while he was aware that a tantra called the Paușkara was often cited by the Kashmirian authorities whose works he studied and emulated, and he had close at hand a text bearing the same title, one which he found useful enough to cite repeatedly in his own doctrinal works, he could never bring himself to refer to the work by its professed title, knowing it to differ from the text known to the Kashmirians. ${ }^{16}$ A similar case is that of the Kammikägama: attested early and often as the foremost text of the Siddhānta canon, and cited repeatedly

15 The pioneering research of Hélène Brunner is an important precursor here. Though modestly eschewing broad conclusions, her study of an organizing liturgical dichotomy in the siddhāntatantras ("Ātmārthapūjā versus parārthapūjā in the Śaiva tradition," in The Sanskrit Tradition and Tantrism. Panels of the virth World Sanskrit Conference, ed. Teun Goudriann, (Leiden: Brill, 1990)) importantly registers the difference between the élite spiritual exercises of ätmārtha worship (that which is "for one's own sake") versus that which is parārtha (as she argues, "for the general good"). Noticing inconsistencies in the description of both modes' central figure of the ācārya (15-17), Brunner was led to conclude that the tantras describing parärtha practice borrowed their model from those regulating independent worship; all of the parärtha-centred works are those that can be assigned to the twelfth century or later by Goodall's criteria. Here, as elsewhere in her scholarly oeuvre, Brunner's meticulously documented work was remarkable in its informing historical imagination. See also Sanderson "The Śaiva Age," 276-279 and the references cited there on the ambiguous status of the Ādiśaiva Brahman sub-caste in the temples of Tamilnadu and their role in the proliferation of temple-tantras.

16 As Goodall plausibly suggests (Bhatțarāmakaṇțhaviracitā Kiraṇavrttiḥ, xliv, n. 101; cf. Parākhyatantra, lii). 
by Abhinavagupta in his Tantrāloka, none of its early quotations appear in the South Indian Kämika, though it has retained the authority of its earlier namesake. ${ }^{17}$

\section{A Case Study: The Sūtasaṃhitā}

Rather than reproduce the results of Sanderson, Goodall, and their colleagues' researches here, I will provide a single example of the post-eleventh century pseudepigrapha, drawing not from the textual corpora of Śaiva or Vaiṣnava initiates, but from the more public medium of purānic literature. This is a work calling itself the Sütasamnhitā ('The Bard's Collection'), which reached its present shape in the great Śaiva temple city of Cidambaram in the mid110os. Arguing for a Śaivized version of Advaita Vedānta (the Veda-congruent doctrine of philosophical non-dualism), the Samhitä's doctrinal exposition is enlivened by descriptive and mythical narrative asides, most of which are centered on Śaiva sites around the Kaveri river delta. The extant version of the text, which was commented upon by a fourteenth century scholar-official called Mādhavamantrin, represents an expansion of an earlier cycle of largely doctrinal materials. The details of this compositional process can be reconstructed with relative confidence, and so furnish a close-up view of the ways in which the Sütasamnitā's author-compilers were participants in the anonymous philology of their time. ${ }^{18}$

The text begins conventionally, hearkening back to the frame narrative of the ancient Mahäbhärata epic: a sacrificial session in the midst of the mythical Naimișa forest is interrupted by the arrival of the bard Romaharșana, and the sages gathered there request the narration of an auspicious collection of stories (saṃitām punyām ) from their guest. The bard proceeds to limn the contours of the purāna genre, again conventionally, listing its eighteen major and minor

17 For the authoritative position of the Kämika, see for example Mrgendrāgama, caryāpāda, vs. 35a; for Abhinava's citations in the Tanträloka, see 1.59, 1.66, 4.25, 6.94, 6.19o, 8.213, 22.32, 23.4, 32.34, 32.48. The "new" Kämika is first cited in the Jñānaratnāvalī of the mid-twelfth century scholar Jñānaśiva (see Sanderson, “The Śaiva Age," 279, n. 663, citing a lecture by Goodall): as in the case of his contemporary Aghora's references to the southern Paușkara, these citations are unattributed.

18 Though I differ in interpretation and in the date I assign to the composition of the Sütasaṃhitā, I rely here on Raghavan's excellent brief survey of the text (V. Raghavan, "The Sūtasaṃitā," Annals of the Bhandarkar Oriental Research Institute 22, nos. 3-4 (1947): 120125). 
instances (1.1.7-18). ${ }^{19}$ The bard's theme for this session, however, is to be the 100,00o verse Skānda (1.1.19). He proceeds to describe that work's division into six saṃhitās or collections, to which he prescribes precise lengths, measured in granthas, the thirty-two syllable quantum by which copyists were paid. Significantly, the 6ooo grantha-long Sütasamnitā is placed second in this list, after the bulky Sanatkumārasamhitā, said at 55,00o verse-units to account for the majority of the meta-text $(1.1 .20,22)$. The bard goes on to sub-divide the Sütasamhitā into four khandas, assigning to each a length more or less that of its extant version (1.1.28-32).

This opening index is thus relatively faithful to the actual contents of the work. It also seems to be the first such bibliographic survey of materials going under the title of the Skānda- or Skandapurāna. Indology had long consigned this work to a shadowy existence, as the locus of attribution to which local purānas were spuriously ascribed, especially the texts called māhātmyas, in praise of the grandeur of a specific temple, river, or other location. ${ }^{20}$ This opinion, however, has been upended by recent research into the earliest surviving claimant to the name, the Skandapurāna that survives in several remarkably old manuscripts, the earliest of which likely dates to $810 \mathrm{CE} .{ }^{21}$ It was only considerably later-the early Skandapurāna's editors have proposed the twelfth century, precisely the period under discussion here ${ }^{22}$ - that texts began to be affiliated with a meta-purāna called the Skanda, texts which in fact refer to themselves as khandas, using exactly the same terminology by which the Sūtasamhitā refers to its own constituent elements.

19 See Travis L. Smith, "Textuality on the Brahmanical 'Frontier'. The Genre of the Sanskrit Purānas," Philological Encounters vol. 1, 347-369.

20 In a representative judgement, the Skandapurāna is "only a name to which extensive works, said to be the Saṃhitās or the Khaṇdas of the original Purāna, and numerous Māhātmyas claim alliegance." The opinion is that of M.A. Mehendale, cited by Rocher (The Purānas, 228-229); Rocher goes on the mention (237) the Nepalese manuscript that transmits the 'original' Skanda. A witty appreciation of the 'Skandapurāna problem' can be found in Wendy Doniger, "The Scrapbook of Undeserved Salvation: The Kedāra khaṇda of the Skanda Purāna," in Purāna Perennis, ed. Wendy Doniger (New York: sunY University Press, 1993). In a sense anticipating my argument here, Doniger writes that the purānic authors of a portion of the expanded Skandapurāna resemble mutatis mutandis contemptorary Indologists in their efforts to bring together and reconcile a range of earlier texts and themes.

21 For the 'original' or 'Ur-' Skandapurāna, see Rob Adriaensen, Hans Bakker, and Harunaga Isaacson, "Towards a critical edition of the Skandapurāna," Indo-Iranian Journal 37, no. 4 (1994): 325-331.

Adriensen et al., "Towards a critical edition," 326 . 
The opening of the Sütasaṃhitā thus has a ripped-from-the-headlines feel to it: it can be understood not just as an effort to pass off a newly confected text under a prestigious banner - though it was certainly that, too-but as an effort to make sense of its wider textual horizon, while supplying an open structure by which further texts could also be so orientated. In this, the Sūtasam hitā appears to have been especially successful: the composers of a mythological narrative cycle with literary ambitions working in Kerala a few generations later, at some point between 1200 and 1313, saw fit to frame their work as a portion of a Jaiminìyasaṃhitā to be found in a "Brahmāṇda-mahāpurāṇa virtuel," in a manner that strongly suggests an acquaintance with the Sütasamnitāa. ${ }^{23}$

The Sütasam hitā authors were remarkable in their attention to prior texts. Many of these are drawn from the Veda, especially the upanișads, and much of the work is given over to a simplified exposition on their nondualist interpretation: Advaita Vedānta for Dummies. At times, however, borrowed language is employed to a more singular effect, as in the text's opening narrative of Śiva's self-revelation, when, in an impressive feat of narrative pretzel $\operatorname{logic}^{24}$

... the divine Rudra [= Śiva] entered into his own complete form. Then the gods-Viṣnu and all the rest—-did not see Rudra. So it was that, with arms upraised, they praised him with the Atharvaśiras, with many other Vedic hymns, and with the revered five-syllable mantra.

Here, as the gods are said to praise Śiva with the Atharvaśiras, a late Śaiva upanișad, the Sütasaṃhitā authors draw upon that same work for their raw material; as Mādhavamantrin notes, the wording here closely adapts that work's own statement, in pseudo-Vedic prose: "then the gods did not see Rudra; the gods meditate upon Rudra and then, with arms upraised, they praise him."25

23 As suggested by Christophe Vielle, "La date de la Jaiminīyasaṃhitā du Brahmāṇdapurāṇa: Une confirmation épigraphique du début du XIvème siècle AD," Indologica Taurinensia 34 (2008): $317 \mathrm{ff}$. (the text's precise terminus ad quem is supplied by a datable epigraphic record, see 322-323); and, more generally, idem, "Transmission et recréation purānique: Le cas du Brahmāṇ̣apurāṇa," in Colas and Gerschheimer, Écrire Et Transmettre, 173187.

24 Sūtasaṃhitā 1.2.11-12: ... bhagavān rudrah svam pūrṇam rūpam āviśat | nāpaśyanta tato rudraṃ devā viṣnupurogamāh || atharvaśirasā devam astuvaṃś cordhvabāhavaḥ | anyair nānāvidhaị̣ sūktaih śrimatpañcākșareṇa ca|

25 Atharvaśiras 1.6 (with shared material in bold): tato devā rudram nāpaśyams te devā rudraṃ dhyāyanti tato devā ürdhvabāhavah stuvanti. 
The texts that are similarly reworked and incorporated into the Sütasamhitā run the gamut of smārta orthodoxy, from the Veda to the Gitta and the Bhāgavatapurāna. ${ }^{26}$

This is all in the service of a recognizably Śaiva project, but one that differed in its mechanics and in its presumed social consistency from the initiatory Śaivism of the tantras. Even this domain, however, fell within the Samhitä's incorporative ambit. This can be seen with particular clarity in the purāna's third major division, the muktikhanda ('section on release'). This concerns the Saiva theory of liberation, and the gradation of the forms of postmortem beatitude into sālokya (existence in Śiva's heaven), sāmīpya (proximity to the divine presence), sārūpya (possession of Śiva's fundamental characteristics of omniscience, omnipotence, and omnipervasion), and sāyujya (fusion). ${ }^{27}$ For the composer-redactors of the Sütasamhitā this four-term series is introduced as that which has been taught in the upanișads (III.2.28ab: śrūyate ... vedānteșu; a statement that Mādhavamantrin unconvincingly attempts to justify) only to be unfavorably compared to the complete, nonrelational liberation (III.2.35a: paramā muktiḥ) that is the Sütasaṃhitä's own apex-point. The Śaiva hierarchy is then reintroduced as the subordinate (III.2.36d: paratantrāhn) forms of liberation. Here the text betrays a certain ambivalence towards its Śaiva source material, which are both affirmed and held at arm's length. This system of liberation in stages (kramamuktih) is extrapolated out of its strictly Śaiva context, as each of the four grades is respectively correlated with the transectarian trinity of Śiva, Viṣnu, and Brahmā (III.2.40-47ab). It is essential to see the resulting eclectic synthesis not as a collision of unreconciled sources, but as a deliberate textual strategy, a harmonization of diverse materials within the text's own structure.

26 See here Raghavan's extensive (though incomplete) catalogue of these borrowings (Raghavan, "The Sütasamhitā," 120-125).

27 The history of this set of four is obscure: seemingly the earliest list in which these four occur (with sāmnidhya in the place of sāyujya) can be found in the Mātangapārameśvarāgama, yogapāda 5.63 ff., where they appear as part of a larger set of seven kinds of liberated souls (I thank Dominic Goodall for this reference). Kashmirian exegetes from the eleventh century and after used a three term set (the Sütasaṃhitä's set excluding sārūpya) and only for the inferior forms of liberation: thus Kșemarāja ad Svacchandatantra 10.787cd-788ab and Jayaratha ad Tanträloka 13: 245cd-246ab. In later South Indian literature, for example in Vedajñāna's Śaivāgamaparibhāṣāmañjarī (ca. 1550), they are established as the set of four we see in the Sütasaṃhitā; the set of four may be a peculiarly southern development, as it is also found in the Tamil Tirumantiram (of uncertain date, but most likely assembled after the emergence of the new Tantric corpus). 
The work of incorporation and adaptation seen here may have begun in an earlier recension of the work. The final chapters of the muktikhanda appear to provide a bridge between an earlier version and the extant text. The entire muktikhanda is framed as a dialogue between Śiva and Viṣnu, with only very occasional interjections by the Süta, the text's ultimate narrator. This arrangement abruptly changes in the section's eighth and penultimate chapter, where the sages - for the first time in the whole khanda — ask a question of the Süta: what did Viṣnu do after he had acquired this knowledge of ultimate things from Siva? He brought these teachings to the gods, the Süta explains, having used Cidambaram (III.8.2d: vyāghrapura) as a launching pad for his return flight to his heavenly home in Vaikunțha: this marks the text's first entry into real-world geography. When the other gods asked to hear the secrets that has been imparted to him, Viṣnu demurred, pointing to his own unworthiness as a teacher, and tells them to take themselves to Cidambaram (III.8.8d: pundarīkapura) and there offer worship to Śiva themselves.

The Süta again takes up the narration, this time with a noticeable shift in flavor: while most of the Sütasamhitā is written in the brusque economy of the anuștubh meter, here it shifts a series of heavily enjambed verses written in the longer verse-forms that are usually the preserve of literary writing. In these, the narrator describes the gods' audience with Śiva (III.8.27-30):

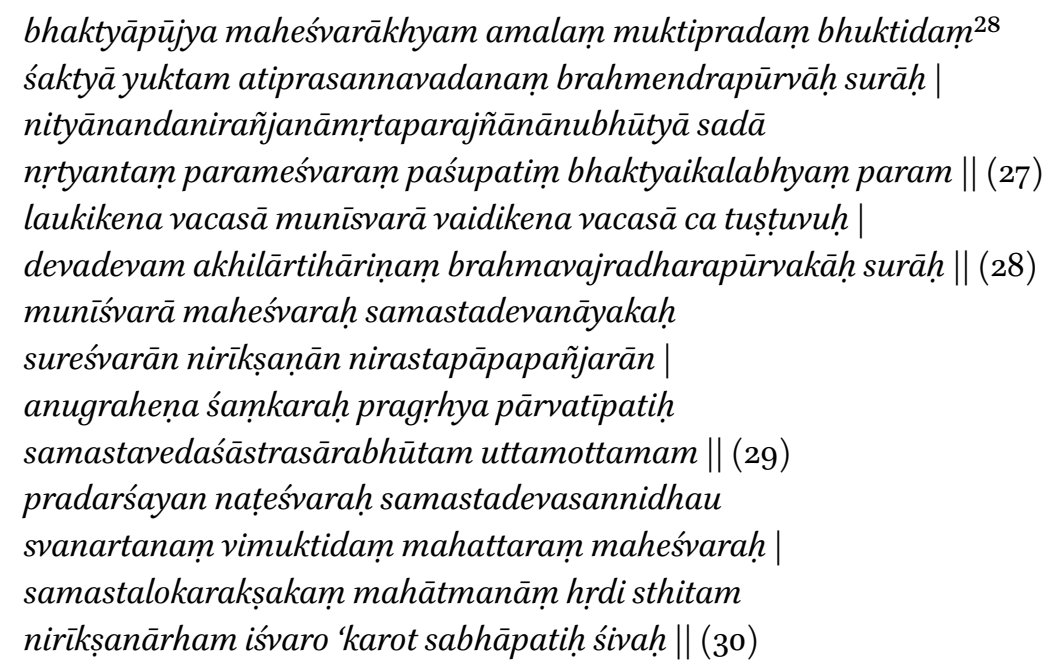


The gods, led by Brahmā and Indra, once they had devoutly honored the stainless one called Maheśvara, the giver of liberation and of [karmic] experience, who is joined with his Power and whose face is exceedingly bright, God himself, the lord of creatures, the ultimate, who can only be approached through devotion and who forever dances through the power of his insight, the highest wisdom that is undying, stainless and everjoyful,

Oh sages, led by Brahmā and the wielder of the vajra, the gods praised with the words of the Veda, and with worldly speech the God of gods, who removes all afflictions.

Sages-Maheśvara, the master of all the gods, did in his mercy receive the greatest of the gods, all of whose sins fell away at his gaze, and then Śamkara, the husband of the Mountain Goddess and the Lord of Dancers, while he was performing his unique dance in the presence of the gathered gods - the utterly sublime, the essence of all of the Vedas and the śāstras, that greatest of dances, which gives total liberation, maintains all of the worlds, and abides in the hearts of the great - the master of the Assembly, Lord Śiva, made his dance manifest to them.

In terms of their narrative content, these verses are completely conventional: the gods praise Śiva and he begins to dance. It is their form that is of particular interest, first of all in the shift to the longer kārya metres. This is a way of the text drawing attention to itself, breaking with the standard epic verse that dominates it. This formal 'thickening' is further borne out by the individual verses, in a surprising way: the first verse, written in the art-metre śärdūlavikrị̣ita, employs front-rhyme, a figure of sound that is known (as dvitīy ākșaraprāsa) yet extremely rare in Sanskrit, but which (under the name ětukai) is so common as to be obligatory in medieval Tamil. The final two verses-in the rare pañcacāmara metre-are composed with an obvious priority given to their rhythmic cadence, and contain a spellbinding display of internal rhyme and assonance, again features diagnostic of contemporaneous Tamil poetry, and hardly something one expects to see in a Sanskrit purāna.

The point bears emphasis: as the composers of the Sütasamnitā shift the scene to Cidambaram, the language of the text itself changes and adopts highly marked 'Dravidian' formal features. This establishes a tension in the narrative, as ultimate things are set self-consciously within a resolutely local, historical world: the Sütasaṃhitä's Vedāntic truths are by definition timeless and placeless, and the vision of release offered up by the text is the state of com- 
plete non-relation, of pure being without becoming. Yet these truths are situated in a particular point in space and are introduced in language that bears the recognizable stamp of the regional and the circumscribed. This tensionbetween the universal and the particular, between the text's cosmic vision and its own backyard, so to speak-is then resolved by a moment of narratological vertigo. The sages again interrupt the Sūta: how can we see this dance of Siva's (3.9.3ab)? Thereupon the whole crew-the narrative bedrock of the entire text-shifts from their sacrifice in the mythical Naimișa forest to Cidambaram.

This shift in multiple registers of the text's language, rhetoric, and spatial imagination suggests that these two final chapters of the third khanda were a Cidambaram-specific addendum to an already-existing text. These chapters supply a bridge to the vast bulk of the Yajñavaibhavakhanda which, at 4000 grantha verse-units, is about twice as long as the Sam hitä's other three sections put together. The Yajnavaibhava is itself focused on Cidambaram among the many Śaiva sites it mentions: unlike the three antecedent sections, it is as much concerned with local myth and pilgrimage circuits as it is with Vedāntic précis. Even by the forgiving standards of the rest of the text and its genre, its language is repetitive and frequently clumsy; it is also the portion of the text that is most given over to quotation and borrowing, both acknowledged and unacknowledged. ${ }^{29}$

Textual history thus permits some cautious inferences about the authorial intention that underlay the revision and expansion of the Sūtasamhitā into its extant form. Evidently, the expanded text's author-compilers, resident in Cidambaram, took up the earlier narrative and doctrinal cycle and expanded it: both the opening sketch of the Sütasamhitā within the scheme of the Skandapurāna and the localization of the muktikhanda's conclusion to the temple-city would be products of this redaction. They then used this expansible purānic matrix as a sort of library for an anthology of passages drawn from all over the orthodox textual imagination, considerably building upon the work of their own anonymous predecessors. ${ }^{30}$

29 These features of the section's language and structure were already noticed by Raghavan, "The Sütasamhitā", 246.

$30 \quad$ Further evidence of this process is detailed in Whitney Cox, "Purānic transformations in Cōla Cidambaram," in Pushpika: Tracing Ancient India Through Texts and Traditions. Contributions to Current Research in Indology, Volume I, ed. Nina Mirnig, Péter-Dániel Szántó and Michael Williams (Oxford: Oxbow Books, 2014), 25-48 where a narrative set in Cidambaram found in the text's first and fourth khandas is compared to a parallel version in another local purānic collection, the Cidambaramāhātmya. 
The received text appears to have emerged in the middle decades of the twelfth century, in the midst of the rapid transformation of Cidambaram into a regionally significant religious center and, spread over its wider cluster of nearby brahmadeya villages, the site of a distinctive brahmanical culture. Contemporary epigraphy reveals a micro-region overwhelmingly dominated by brahmans, many of whom were marked out by the anomalous names of their gotra or endogamous clan. ${ }^{31}$ These may have been recently brahmanized local elites, or the members of a resolutely local subculture only just beginning to acclimatize to transregional norms of caste comportment. In any case, the Sütasamnitā emerged from this world as an enormous work of synthetic, harmonizing scholarship, and as a charter for what this newly fashioned élite could be: negotiating between Vedāntic orthodoxy and the glamour of initiate Śaivism, the text argues for a new way to be a brahman and a worshipper of Śiva, and to be embedded in a local world and its particular structures of meaning, while speaking in the universalising register of the pan-Indic purānas.

\section{Methods of the Anonymous Philology: The 'Toolkit'}

Pseudonymous texts like the Sütasaṃhitā and the Śaiva and Vaiṣnava tantras have generally been regarded as the objects or the subject matter of philological study, whether of the premodern style of learned commentary (such as Mādhavamantrin's gloss on the Sütasam hitā) or the contemporary sort of critical editorial intervention and analysis practiced so admirably by Sanderson and Goodall. These texts can, however, be profitably understood as philological scholarship in their own right, in that they possessed certain recognizable methods of orientating themselves within and with respect to a preexisting corpus of texts. There are two central aspects to what I consider their anonymous authors' philological toolkit, what may be termed their methods of textual integration and of bibliographic organization.

By the first of these, I refer to the characteristic habit of taking over pieces of prior texts and suturing them into a new argumentative or doctrinal context. These works were critically invested in a project of making sense of a particular textual past, in assembling, comparing, integrating and, in some cases,

31 See Leslie Orr, "Temple Life at Chidambaram in the Chola Period: An Epigraphical Study," in Śrī Puṣpāñjali: Dr. C.R. Srinivasan Commemoration Volume, ed. K.V. Ramesh (Delhi: Bharatiya Kala Prakashan, 2004), 231-233; and Cox, "Purāṇic transformations" and Politics, Kingship, and Poetry, pp. 188-189. 
hijacking the language of earlier authorities and presenting a new synthesis of it within the authoritative frame of an imagined, mythic authorial voice or voices. This kind of incorporative logic of textual composition can be seen throughout these corpora, especially but by no means exclusively when the materials being incorporated pass across the boundaries of religious traditions. This wholesale borrowing and reworking of existing texts was frequently the result of very serious engagement with the argument and the verbal texture of demanding source materials. Indeed, Sanderson's pathbreaking study of these dynamics ("History through textual criticism"), which sets out the broad picture that he, Goodall, and their colleagues and students have subsequently continued to detail, relies for evidence on the cases where this process misfires, where-whether through inadvertence or misunderstanding - the resulting text reveals the traces of its precursor. These momentary lapses should not, however, detract from the overall accomplishment of these works' authors. Their compositional practice can neither be characterized as simply quotation nor as an instance of some nebulously conceived idea of influence, nor still as a case of simple plagiarism. It is instead evidence of a mode of reading, interpretation, and composition in which the prior text stands in a privileged, if not always acknowledged, place.

These works' incorporative style of text-making - the way they take over and integrate existing texts-constitutes an important part of their philological techniques. But the methods by which their authors operated extended beyond this, to the pseudepigrapha's strongly bibliographic orientation. This refer to the ways in which they evince knowledge of prior textual corpora and seek to include themselves within them, by presenting arguments for textual hierarchies, offering explicit filiations with preexisting texts, or placing themselves within the larger, often virtual, setting of a meta-text, in a way that Ronald Inden (after Collingwood) has called the articulation of a scale of textual forms. ${ }^{32}$ The Sütasaṃhitä's articulation of a superordinate Skandapurāna, consisting of a series of khandas and samphitās, is a prime example of this. Again, this is by no means unique to works composed in the Tamil country from the late eleventh century; nevertheless, there is a definite increase in such bibliographic projects

32 See the discussion in Ronald Inden, Jonathan Walters and Daud Ali, Querying the Medieval (New York: Oxford University Press, 2000), 48-54. Inden himself would no doubt resist this characterization, insofar as he polemically (and over-simply) rejects 'philology' as an adequate disciplinary practice (see e.g. Querying the Medieval, ${ }_{5} \mathrm{ff}$.), understanding it tout court to be an instance of "contextualism" which "assumes textual essences to be material and to belong to the objective linguistic $[\ldots]$ structures $[\ldots]$ that impinge on individual authors from outside." 
in the works produced there and then. More to the point, some of these projects quite explicitly localize themselves in the physical, as well as the textual, terrain of the far South.

Exemplary here is a passage found interpolated into the opening chapter of the Pañcarātra Jayākhyasaṃhitā. Dubbed 'adhikah pāthahh' ('additional reading') by its modern editor, this text neatly captures the effort of some reader(s) of the Jayākhya to situate that work within the proliferating Pañcarātra canon, and within the temple cultures which furnished the canon's institutional setting. ${ }^{33}$ Evidently this passage reached its published form at some point close to the fourteenth century, almost certainly in the ancient temple city of Kãñcīpuram. ${ }^{34}$ The interpolation's author reveres what modern scholarship would agree to be three early authorities-the Jayākhya itself, the Sāttvata, and the Pauṣkara - as the 'Three Jewels' (vs. 2) of the Pañcarātra revelation, arguing that all other scriptures are dependent on these for their authority (vv. 4-5). The author then goes on to elaborate a relation of dependence between these three leading works and what are demonstrably later temple tantras (respectively, the Pādma-, İśvara-, and Pārameśvarasamnhitās), which relate to the Jewels as a commentary to a root-text (vs. 6) while- unusuallyeach of the Jewels is said to function as a commentary on the other two. ${ }^{35}$ Each of the pairs of scriptures, with the subordinate text explicitly demoted to a liturgical manual (käryakāri, v. 14), is then connected with three major Vaiṣnava temple sites of the far South, the Varadarāja temple in Kāñcī ("Elephant Hill" or hastigiri, the home to the Jayākhya-Pādma tradition), Śnirangam (PauṣkaraPārameśvara), and Melkote in the southern Kannada country (nārāyanạāri, Sāttvata-İ́svara).

This is just one of several such efforts to rationalize the textual cosmos of the Vaiṣnavas. But this vision of the Pañcarātra canon is especially eloquent in the

33 Existing scholarship on the adhikah pāṭhạ includes K.V. Soundara Rajan, "Kaustubha Prasada-New Light on the JayakhyaTantra," in Glimpses of Indian Culture: Vol. 2, Architecture, Art and Religion (Delhi: Sundeep Prakashan, 1979), 26-35; Marion Rastelli, "Zum Verständnis des Pāñcarātra von der Herkunft seiner Saṃhitās," Wiener Zeitschrift für die Kunde Südasiens 43 (1999): 51-93; and Robert Leach, "The Three Jewels and the Formation of the Pāñcarātra Canon," unpublished paper, forthcoming; see also Alexis Sanderson, "History through Textual Criticism," 48, n. 5 o.

34 On this date, see Rajan, "Kaustubha Prasada", who is followed by Rastelli and Leach.

35 Jayākhyasaṃhitā 11cd-12ab: mūlavyākhyānarūpatvād upajūryam parasparam || tantratrayam idam vidyād ekaśästram tathä budhaḥ, "These three tantras are mutually reinforcing, taking the form of root-text and commentary for each other. Thus the wise man understands them to form a single teaching." On this last claim see Rastelli, "Zum Verständnis," 54, n. 12 and Leach, "The Three Jewels," 4. 
way it captures the negotiation of a textual tradition in a state of evident flux, buttressing the validity of older texts while securing for them a place within the transformed world of the religious culture of Cola and post-Cola Tamilnadu. The interpolation goes on to give a lengthy description of the wondrous mythic history of Kāñcipuram, only returning at the end of a lengthy mythic māhātmya of Hastigiri (vv. 20-107) to the theme of the textual authority of the pairs of tantras. By offering this sort of textual and locational hierarchy, and interpolating it at the head of a foundational authority, the author of the adhikah pāthah created a meaningful philological intervention, at one stroke making sense of the complex present while supplying a warrant for future understanding.

He was hardly unique in so doing. In this, and in the long-term effects that this textual incorporation would exert, the creators of these tantric scriptures are in some ways comparable to the classical and early modern European forgers discussed by Anthony Grafton. ${ }^{36}$ While it is probably going too far to globally condemn these tantras as 'forgeries,' in that they do not embody an effort to traduce or deceive their intended audiences — though recall Jayanta Bhatța's Black-Cloaks! - still they share with the spurious European works a concerted effort to erect their own claims to authority upon the foundation of existing, putatively reliable works. More significantly, as in the case of arch-forger Annius of Viterbo's influence on early modern European historical thought, these works adumbrated philological protocols of interpretation and composition that would provide a model for other works.

\section{Appropriation and Adaptation: Cekkilāâ’s Pĕriyapurāṇam}

While tantric and purānic literature provides compelling evidence to document this new dispensation of text-making, this is a phenomenon which stretches well beyond just these doctrinal and ritual texts. This same sort of pseudonymous philology can be seen to remarkable effect, for example, in the literary and dramatic theory expounded in the Bhāvaprakāśana of Śāradātanaya, who-as we will see in the next chapter-rewrote existing authorities

36 Anthony Grafton, Forgers and Critics: Creativity and Duplicity in Western Scholarship (Princeton: Princeton University Press, 1990) and Defenders of the Text: The Traditions of Scholarship in An Age of Science, 1450-180o (Cambridge: Harvard University Press, 1991), esp. 76-103 and 162-177; Anthony Grafton, Glen Most, and Salvatore Settis, eds., The Classical Tradition (Cambridge: Harvard University Press, 2010) s.v. "Forgery". For broadly comparable Indian cases, focusing on epigraphy, see Richard Salomon "The Fine Art of Forgery in India," in Colas and Gerschheimer, Écrire Et Transmettre, 107-134. 
and invented new sources altogether to produce an idiosyncratic synthesis of the state of these disciplines from the perspective afforded by the local aesthetic sensibilities of the far South. The relationship between the anonymous philologists' work and that of the Tamil Śaiva poet and hagiographer Cekkilār is more oblique, but it brings both into greater focus, like a torch's raking light held up to a bas-relief whose details are otherwise lost in shadow. Like the Sütasamnitā, Cekkilāar's work was a product of the Saiva temple centre of Cidambaram in the middle of the twelfth century; again like that Sanskrit work, it styled itself as a purāna, an account of the past. ${ }^{37}$ However, the two self-styled purānas differ widely, most obviously in their language-Cekkilār's Pěriyapurānam (the 'great' purāna) was composed in Tamil, a language with a centuries-long literary pedigree but without any necessary claim to transcendent supernatural authority. It thus could not claim for itself the privileged epistemological and narrative space of compositions in Sanskrit; it also possessed an openly professed human author in Cekkilār, the scion of a family of landed gentry otherwise known from epigraphy. ${ }^{38}$

The Pĕriyapurānam is a hagiographic cycle on the lives of the nayanmār, the foremost devotees of Śiva in the far south, loosely structured around the lifestory of Cuntaramūrtti, the last of the trio of Śaiva hymnists. In clear contrast with the workmanlike style of a self-professed purāna like the Sütasamnhitā, the Perriyapurānam was a text of major formal and literary ambition. Yet it was the product of a compositional logic that was, in many ways, cognate to that of the Sanskrit pseudepigrapha, beginning from the self-description embedded in its title. There had evidently never been a purāṇa like Cekkilāar's when he debuted his work, or at least not within the scope of Śaiva theism. For all that the Perriyapurānam palpably differs in subject matter and in its expressive aims from the doctrinal purānas and tantras preserved in Sanskrit, we can observe within it a precocious and sensitive literary reaction to their new philological orientation.

37 This survey draws upon my earlier work on both texts: see Whitney Cox, "The Transfiguration of Tinṇan the Archer," Indo-Iranian Journal 48, nos. 3-4 (2005): 223-252; idem, "Making a tantra in medieval South India: the Mahārthamañjari and the Textual Culture of Cōla Cidambaram" (Ph.D. Dissertation, University of Chicago, 2006), 59-93; idem, "From Āvaṇam to Purānam," Dimensions of South Asian Religion. soAs Working Papers in the Study of Religions, ed. T.H. Barrett (London: The School of Oriental and African Studies, 2007), 5-34.

38 On the poet and his brother's epigraphic profile, see especially Mu. Irākavaiyañkār, Cāsanat Tamilk kavicaritam (1937), 70-78; an uncredited English synopsis of this can be found in K.A. Nilakanta Sastri, The Cōlas (Madras: University of Madras Press, 1955), 676. 
It is thus useful to briefly linger in some detail over Cekkilār's verse-craft, with an eye to tracking the effects of the incorporative and bibliographic philological modes in its very different textual context. There are two areas in which I will class these effects here: Cekkilāar's self-reflexive presentation of the structure and genre of his long poem, and his conspicuous effort at a key narrative juncture at a form of textual integration. When, in its tenth invocatory verse, Cekkilāar explicitly names his work the Tiruttọnțarpurānam ("the purāna of the holy devotees of Śiva"; its conventional title is a later honorific), this marks quite possibly the first time anyone had ever so described a work written in Tamil, although in its wake purānam was to prove a highly productive genre in the language. ${ }^{39}$ The sense of this genre-taxon however differs from that of the Sütasamnitā: the Perriyapurānam is much closer in its form and design to the Jaina universal histories that share this title than to any brahmanical texts; ${ }^{40}$ indeed, this adoption may have been an aggressively assimilating gesture, assimilable to the uncredited inter-traditional textual borrowings that characterize the tantric canons of the Śaivas, Vaișnavas, and Buddhists. This polemical gesture is further evident at a deep structural level: Cekkilāar's poem celebrates sixty-three individual nayanmār, a pointedly identical reckoning to that of the sixty-three śalākāpurușas, the exemplary men of the Jaina tradition.

The Perriyapurānam's opening does, however, gesture towards the narrative conventions typical of purānas like the Sütasaṃhitā (vs. 23-50), framing the text as the reported speech of the sage Upamanniyan (Skt. Upamanyu) to a group of his ascetic followers. The sage's account, moreover, touches on

39 See V. Raghavan, "Tamil versions of the purānas," Purāna 2, no. 2 (1960): 225-242; David Shulman, Tamil temple myths: sacrifice and divine marriage in the South Indian Śaiva tradition (Princeton: Princeton University Press, 1980); and Ludo Rocher, The Purānas, 77. Raghavan refers to a number of early examples, for example a Purānacākaram cited in a work on prosody; he further claims that the Tiruttŏṇtattǒkai (one of Cekkilāar's principle sources, see below) is referred to as a purānam, a claim for which he cites no evidence.

40 This is convincingly argued by Indira Peterson, "Śramanas against the Tamil way," in Open Boundaries: Jain communities and culture in Indian history, ed. John Cort (Albany: SUNY Press, 1998). A number of such works were produced in the centuries before Cekkilār's time in the nearby region of what is now Karnataka: Jinasena's Ádipurāna, Guṇabhadra's Uttarapurāna (both in Sanskrit), Puṣpadanta’s Apabhraṃśa Mahāpurāṇu, and Cāmuṇḍarāya's Kannada Ādipurānam (the last of these Peterson suggests as a particularly apt candidate for what she terms the Periyapurānam's "shadow-text"). Peterson notes the aggressive undertone that this generic adaptation possesses, given the historic conflicts between Tamil Śaivas and Jainas, an explicit topos of Cekkilār's account of the lives of the two nāyañmār Appar and Campantar. 
the incarnational back-story of Cuntaramūrtti's life on earth; in particular, his previous birth as a heavenly courtier in Śiva's kingdom on Mt. Kailāsa, a framing narrative reminiscent of the conventions of both purāna and belleslettres. Cekkilār's adoption of the label purāna to describe his work was thus deliberately ambiguous, gesturing at once towards a polemical target and an authoritative textual model.

The similarities to the sort of philological practice we have been tracing do not end with the work's professed genre. Throughout, Cekkilār's poem embeds brief quotations from the corpus of Tamil Śaiva bhakti hymns, principally in its narration of the lives of the three singer-poets Cuntaramūrtti, Tiruñannacampantar, and Tirunāvukkaracar. In a sense, the Pěriyapurānam serves as the only early commentary to this corpus, interpreting individual hymns as reflections upon moments in the nāyanmāar's life-stories. ${ }^{41}$ More to the point, Cekkilār remarkably—and in my reading uniquely—reflects upon his own process of poetic composition. Following upon the initial 'purānic' conversation where Upamanniyan lays out for his disciples the previous divine incarnation of Cuntaramūrtti (commonly referred to as vañrŏnțar, 'the harsh devotee'), Cekkilār addresses his audience directly: ${ }^{42}$

In accord with the manner in which that great sage did then speak of the deeds of the harsh devotee, so now I do reverently compose here an exposition [viri] on the Tiruttŏnțatǒkai, of great fame among the devout.

That is to say, the fine verse-text [narpatikam] that is called the true Tiruttonntatŏkai, which the harsh devotee himself uttered through the favor of our ancient lord who dwells in the Anthill, has been worshipfully adopted as the guideline [patikam] for this [work].

41 One may contrast here the commentarial attention given to the parallel corpus of the hymns of the Vaiṣnava Ālvār poets, above all Nammālvār's Tiruvāymōlizi: see, e.g. Francis Clooney, Seeing through texts: Doing Theology among the Śrvivaiṣnavas of South India (Albany: sunY Press, 1996); and Srilata Raman, Self-Surrender (Prapatti) To God In Śrivaiṣnavism: Tamil Cats and Sanskrit Monkeys (New York: Routledge, 2007).

42 vv. 47-49 ĕñru māmuñi vañrōnțtar cĕykaiyai / añru connnnapațiyāl ațiyavar / tuñru cīrtirut-

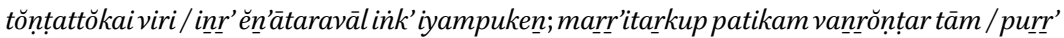

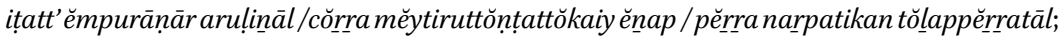
anta mĕyppatikatt' ațiyārkalai / nantanātañā nampiyāṇțārnampi / puntiyārap pukañra vakaiyiñāl /vantav āru valāmal iyampuvām. 
We will compose this without deviating from the path laid out by the expansion [vakai] that our master Nampiyāṇțānnampi crafted in order to fill it with the slaves of the Lord found in that true verse-text [mĕyppatikam].

These call for some unpacking. "The ancient lord who dwells in the anthill," first of all, is Siva as he is worshipped in the great central Tamilnadu shrine of Tiruvārūr, while the Tiruttŏnțtattǒkai ("Litany of the holy devotees") is a brief devotional composition attributed to Cuntaramūrtti himself, essentially a bare list of the names of the seventy-one individuals or collectives, all of whom the poet-and thus the text's subsequent reciter-declares himself in a refrain to be the slave or servant (ațiyen). This work provides a structuring armature, almost a table of contents, for Cekkilār's long poem, hence 'guideline'. At first glance, verse 48 seems to rely on a pleonasm: itarkup patikam ... narpatikam: "the good patikam is the patikam for this [work]." This relies on the complicated historical semantics of this noun: attested in the classical Tamil of the Cankkam period (it is the term used for the poetic colophons attached to the decads of the Patirrupattu anthology), patikam is surely a tadbhava word, i.e. one whose etymon is found in Sanskrit but which has been morphologically altered. It can, however, be referred to either padya ('verse') or pratîka ('image, face, lemma'), ${ }^{43}$ the latter being just the term for the sort of brief prompting quotations that Cekkilār scatters throughout his work. Evidently aware of these two divergent etymologies, Cekkilār plays upon them here in a piece of metalinguistic showmanship.

The tŏkai text attributed to Cuntaramūrtti had earlier provided the basis for the Tiruttonntattiruvantāti ("Linked verses on the holy devotees") of Nampiyāntạar Nampi, the supposed 'rediscoverer' of the Tamil Śaiva devotional corpus, the Tevāram. ${ }^{44}$ It is this latter work that Cekkilār claims as the proximate model for his own, the original title of which echoed the two earlier compositions. This three part series of brief authoritative text, expansion, and extended exposition was adapted by Cekkilār from the traditions of Tamil grammar and poetics: the terminological series tǒkai-vakai-viri appears, for instance, in the preface

\footnotetext{
43 On these etymologies, see the University of Madras Tamil Lexicon, s.v. "patikam" 2, 3.

44 The evidence of this 'rediscovery' is examined with characteristic skepticism in Herman Tieken, "Blaming the Brahmins: Texts lost and found in Tamil literary history," Studies in History 26 (2010): 227-243, based on the later account of the Tirumuraikanțapurānam. A more hermeneutically charitable account is François Gros, "Introduction: Pour lire le Tēvāram," in Tēvāram: Hymnes Śivaïte du Pays Tamoul, ed. T.V. Gopal Iyer (Pondichéry: Institut Français de Pondichéry, 1984).
} 
to Nakkīranār's commentary on the Iraiyañärakappŏrul, an early work on the theory of erotic poetry, ${ }^{45}$ as well as in the laudatory preface (cirappuppāyiram) appended to Pavananti's grammar, the Nannnūl (ca. 1200) as internal components of its definition of an authoritative text. ${ }^{46}$ The use of such a model in the context of a literary work seems to mark a real innovation, almost amounting to a category error. The Perriyapurānam thus embodies both the incorporative and the organizational-bibliographic modes of philological practice diagnostic of the new texts produced in the far South of its time.

Beyond these opening gestures, Cekkilār's great poem evinces a voracious assimilation of other modes of contemporaneous writing, in a manner that suggests a creatively oblique appropriation of exactly these same methods. This can be seen, for example, in the repurposing of the terms of a Saiva theological controversy in its account of the wild hunter-saint Kaṇappar (vv. 650-83o). ${ }^{47}$ More pointed, and of greater significance to the narrative of the Pĕriyapurānam as a whole, is Cekkilār's sardonic integration of the protocols of the everyday textual culture of his twelfth-century world within his poem. The Tamil country under the Cola emperors witnessed an enormous efflorescence of those documents preserved through lithic inscription; ${ }^{48}$ this is only an index of the far wider proliferation of documentary textuality within the social world of the time. The surviving inscriptional records directly attest to this, in their references to land registers, legal decisions, affidavits, etc., all of which would have been recorded on the fragile medium of palm leaves. It is with an eye set on this perhaps newly ascendant documentary order that Cekkilār structured one of his purānam's central narrative set-pieces, the calling to the Saiva path of Cuntaramūrtti (often called Cuntarar, 'Handsome'). Although the aims of his adaptation of the norms of non-literary, non-learned writing differ from that

45 The Iraiyanār text is ascribed in its commentary, incidentally, to Siva: it marks one of the earliest (and most influential) exceptions to works in Tamil being unable to claim a pedigree of direct divine authorship.

46 Iraiyañārakappŏrul, 12-13. Iraiyanār admits of several kinds of textual authority (nūl), comprising mutal ('original'), vali ('[following the] path'), and cārpu or puțai ('peripheral' or 'partisan') works. The three taxa tǒkai-vakai-viri are described in a verse, ostensibly the citation of an earlier authority; the reference to these in the Nannzül's cirappuppāyiram (ln. 11) notably contradict the testimony of Pavananti himself, who employs the alternative scheme. The model easily maps onto the canonical arrangement of a Sanskrit śāstra, with an authoritative sūtra, a critical vārttika, and an extensive bhāsya, first seen in the grammatical tradition and widely imitated in other knowledge systems.

48 See above, p. 19. 
of the incorporative philology of his time-and Cekkilār's poetic project sets him apart from the didactic, doctrinal methods of contemporaneous Sanskrit pseudepigrapha - it is still worthwhile to closely read just a few pieces of this verse narrative, to see the transformations of the incorporative methods in his hands.

The story of Cuntarar's calling, the Tațuttātkŏnțtapurāṇam or 'The purāṇa of the Intercession' (vv. 147-350), can be considered the primal scene of Tamil Śaiva bhakti, which sets the tone for Cekkilār's whole long poem. The early part of Cuntarar's life is a study in worldly perfection: born in a lineage of observant Śaiva brahmans in the brahmadeyam of Nāvalūr, Nampiyārūran (who would adopt the name Cuntaramūrtti later; both are epithets of Śiva) came of age in an idealized world of learning and cultivation. As Nampi enters adolescence, and the arrangements for his wedding begin, Cekkilār-prefiguring his narrative's central moment-focuses in upon the itinerary of a letter written on palm-leaf as it is carried from Nāvalūr to the village of Puttūr, home to the boy's wouldbe future in-laws. This palm-leaf letter, meant "to set the day" (kurittunāl olai, vs. 156 ) is formally met with by a party of Nampi's fiancée; it is the first of several such text-artifacts that the poet focuses in upon.

On the wedding day itself, moments away from the rite's climax, an uninvited guest suddenly arrives, an old man claiming unfinished business with the bridegroom. We, the audience, are already in on the big secret: the elderly Brahman is Śiva himself (vv. 175-178, 181). The scene Cekkilāar describes possesses a real dynamism, as the gathering crescendo of the wedding festivities is suddenly muted by the mysterious old man, and as the initial good will and hospitality offered to the guest by Cuntaramūrtti gives way to slowly building confusion and anger. The Brahman insists that the bridegroom is his slave, and brandishes a palm leaf document (olai, āvanam) attesting to the fact: the document is signed, it would seem, by young Cuntarar's grandfather. Finally, the handsome and genteel-but rather sheltered and high-strung-young man from Nāvalūr loses his temper (vv. 190-191):

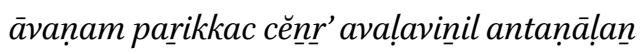

kāvanatt' ițaiyey oțak kațitu pin roŏțarntu nampi

pūvaṇattavarai urrāàr avaralār puranika! cẹrrra

ev'aṇ accilaìiñārai yār toțarnt' ĕțța vallār

maraikal àyina munporrí malarpatam parri niñra

iraivanait toțarntu parrri élutum àlolai vāñ̀i

araikalal aṇnal àlā antaṇar cĕytal ènna

muraiy ẹnak kịriyițțān muraiyițțān muțivilātāan 
As Nampi stepped forward to seize the bond, the brahman ran from the wedding hall, Nampi pursued hard on his heels and grabbed that One who dwells in Pūvaṇam.

Who else could chase down and grapple that One

Whose arrow-nocked bow once destroyed the demons' cities?

He chased down and seized the Lord,

Whose flower feet are grasped only after first praising the Vedas.

That man, his anklets tinkling, grasped the written bond of servitude,

"A brahman made a slave? What is the justice in this?" he said, and he tore it in two.

But the One without limits had spoken true.

Cekkilār's language subtly inflects the scene's incongruity. The word for 'document,' avvanam, begins the first of these verses, and so sets the keynote to its pattern of front-rhyme. The moment depicted there is an absurd one, with the fit young brahman bridegroom chasing down and tackling his elderly accuser, and the rhyme at the head of each line picks up this strain and magnifies it. Cekkilār tacitly sets the scene against Śiva as the indwelling presence in one of his temple homes ( pūvanattavar, the god of Tribhuvanam ${ }^{49}$ ) and as figured in mythology (ev'an accilaiyinār, literally Śiva with 'that arrow-set bow'; here ev'an accilai fulfills the rhyme scheme with a burst of unexpected abbreviation). Alongside the steady pattern set by the ĕtukai, however, the structure of the verse lurches through a series of staccato parataxes: Cuntarar leaps for the palm leaf, Siva scampers away; Cuntarar is hot on his heels; he catches up to him; who but he could do this? In the next verse, by contrast, Cuntarar remains at center stage, appealing to his family and guests before ostentatiously destroying the offending evidence.

Already, we can see that the crux of the narrative hangs on an otherwise banal scrap of text, as an unassuming cadjan leaf becomes the source of contention between the mysterious stranger and our quick-tempered hero. What follows is, to say the least, unexpected: God insists that they go to court. Telling Cuntaramūrtti that the original document (mūlavolai) is held in his home, the brahmadeyam of Vẹṇẹynallūr, the disguised Śiva sets out, with the wedding party in his wake. There, the proceedings take what we may, with David 
Shulman, characterize as a turn to the Kafkaesque, as a surreal deliberation takes place before the members of the town's governing sabha ${ }^{50}$ While the eminent men of the town first wonder aloud at exactly the same outrage as Cuntaramūrtti - can a brahman be made a slave, even to another man of his caste? - the old man, the 'trickster' or 'master of māay' (māyai vallan, v. 202) continues to insist that the original palm leaf document be produced, to substantiate his claim. As the old man produces the original deed, ${ }^{51}$

The councilmen looked at the palm in the hands of the One Whose throat is shrouded in darkness, and gave their assent. The council's karanam bowed and took the bond.

Removing the cloth in which it was wrapped, he opened it and, noting its age, he read it aloud,

while the learned men of the sabhä marked his words.

This verse, with its closely observed details of the karanam or clerk going about his business, immediately conjures up the world of the official written world in Cekkilār's day. These details of housing original documents, and of assessing the validity of prior claims to property are the stuff of the surviving epigraphical texts, pieces of officialese here distressingly introduced into the uncanny scene of the deliberations of Cuntaramürtti's future. The real centerpiece here, however, is what follows: 52

'This is the deed of Ārūran, Ādiśaiva of Nāval, town of the rare Veda:

This document does affirm that I hereby do render myself and all my descendants to perpetually serve Pittan of Vĕṇṇeynnallūr, a great sage.

Being of sound mind and body, I have written this.

Attesting to this, here is my signature.'

50 David Shulman, Songs of the harsh devotee: The Tēvāram of Cuntaramūrttināyanār (Philadelphia: Dept. of South Asia Regional Studies, University of Pennsylvania, 1990), xv-xvii; see also xxvii-xxxiv.

$51 \quad$ v. 204: iruṇmurai mițarrron kaiyil olai kaṇț' avaiyor eva / aru!̣ẹru karaṇattān̄um àvaṇan tọ̆lutu vānkic / cura!̣ẹru muțiyai nīkki viritt' atan roŏnmai nokkit /tĕrulpẹru capaiyor kẹtpa vācanañ cĕppukinrrāñ.

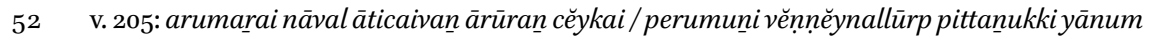

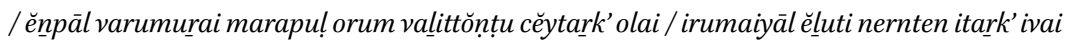
ĕnnnẹluttu. 
We see here a piece of totally mundane, official language, from its formulaic circumlocutions to the mention of its authorizing signature. This is the sort of thing that literally covers every available surface of the temples of the region, in what are only the surviving fragments of what must have been an infinitely more wide-ranging public discourse, carefully and ingeniously crafted into rhymed, metrically complex Tamil verse. ${ }^{53}$ What follows, with the members of the sabha checking to see that, yes, in fact the signature matches a sample of Cuntarar's grandfather's hand, fills out the intentionally absurd proceedings. With his new servant trailing behind, the old man enters the town's temple and disappears, and Cuntarar, realizing what has transpired, sings his first hymn, on Vĕṇnẹynallūr, beginning his life of wandering the Tamil countryside and composing inspired songs of praise to the many locales of its Śaiva religious landscape. ${ }^{54}$

What to make of this reliance on the notarial norms of the public textual culture of the time? Taking what was no doubt an already circulating story about Cuntaramūrtti, Cekkilāar is able to draw the story into much higher relief, pushing against the tension between the comfortably everyday world of shared public lives and selves and the radically inassimilable nature of the transcendent, what is after all precisely the stakes in the nāyanāar's coming to the Śaiva path. We can see here that much of the considerable literary power of Cekkilār's religious epic can be profitably understood as a radicalization of the methods that were distinctive of the philologies we have been tracing, a radicalization that nearly prefigures the heteroglossic novel in its desire to integrate as many as possible of the linguistic registers proximate to it.

53 Orr's discussion of bonded slavery in the Cola period is highly suggestive: while slavery was never a major feature of the epigraphical record, she notes that the final period of Cola rule was marked by a relatively dramatic increase, with more than ninety percent of all references to slaves found in the twelfth and thirteenth centuries (Leslie Orr, Donors, Devotees and Daughters of God: Temple Women in Medieval Tamilnadu (New York: Oxford University Press, 2000), 118). Save one reference to (presumably male) temple drummers and occasional mentions of the male offspring of slave women, almost every recorded instance of a slave is female, mostly involved in menial kitchen labor. This potentially adds another dimension Cekkilāar's depiction of Cuntaramūrtti's crisis, as the heteronomy of enslavement takes on additional, gendered undertones. To be a Brahman and a man is to be doubly removed from the plight Cekkilār depicts here.

54 The famous first words to this patikam — pittā piraicūți, 'Madman, moon-crested!'-are quoted by Cekkilār in v. 220. Notice that the name with which Cuntaramūrtti addresses Siva here, pittan, is the same as that found in the document produced before the sabha in v. 205, cited above. Cekkilār deliberately literalizes the earlier poetic effusion of the Tevāram poem by retroactively recording the name as that of a party to the contract. 
To be certain, the new philology is not the single solvent in which to dissolve all of the questions raised by the Perriyapurānam, any more than it resolves at a stroke all of the problems of the cultural history of this time and place. The Perriyapurānam is a literary masterpiece and a work deeply invested in an overwhelming vision of devotion to God, and it certainly should not be entirely reduced to the self-aware application - or perhaps the equally selfaware parodic adaptation - of the habits of textual scholarship. Nevertheless, it cannot be totally dissociated from these practices. Cekkilār's complex engagement with the emotional energies of southern Śaivism, and his ambivalent reflections on the transvaluation of social norms and the limits of such transformations within a normative religious ethics, ${ }^{55}$ are crucially orientated by his wide-ranging adaptations and homages, and his explicit efforts to craft a new generic model for his great work.

There is a discernable social project at work in Cekkilāar's poem, just as there is in his Cidambaram brahman contemporaries' Sütasamnitā. The Tamil Śaiva poet, a member of the landed élite of the northern marches of the Cola kingdom, wrote at a time when the centuries-long imperium of that dynasty had begun to give way to a newly fissiparous political and social order. In its attempt — at once scholarly and poetic, devotional and parodic — to integrate the different registers of his contemporary world within the ambit of a Śaiva religion framed in Tamil, Cekkilār's project in the Pěriyapurānam seems at once conservative and revolutionary, an effort to negotiate a future through the resources of the textual past. ${ }^{56}$ And it was an effort that would prove remarkably successful: Cekkilār's purānam on the Tamil Śaiva past was to exert a powerful reality effect, becoming in effect the sole lens through which to

55 To briefly gloss two recent interpretations of Cekkilār: see Anne Monius "Love, Violence, and the Aesthetics of Disgust: Śaivas and Jains in Medieval South India," The Journal of Indian Philosophy 32 (2004); and Sascha Ebeling, "Another Tomorrow for Nantanar: The Continuation and Re-Invention of a Medieval South-Indian Untouchable Saint," in Geschichte und Geschichten. Historiographie und Hagiographie in der asiatischen Religionsgeschichte, ed. Peter Schalk et al. (Uppsala: Uppsala Universitet, 2010), 433516.

56 See Cox, Politics, Kingship, and Poetry, and compare Heitzman's conclusions (Gifts of Power: Lordship in an early Indian state (Delhi: Oxford University Press, 1997)) when describing the secular trend of 'intermediate authorities' coming to identify more with the royal center, precisely as they began to exercise more independent authority; see esp. 202: "Increasingly in the twelfth century, and almost completely in the thirteenth, local contacts become buried beneath lordly titles and official transactions, perhaps an appropriate response to the shifting political fortunes as the empire disintegrated." 
view that past: "C' est le mirage de Cekkilāar," as one of his most acute modern readers put it, "auquel l'historien tente vainement d'échapper car le passé qu' il reconstruit ne se dissociera plus de notre magicien du XIIe siècle et de ses suggestions impératives." 57

\section{Conclusions: Looking Ahead}

Cekkilār was precocious in his adoption of the techniques of his world's anonymous philologists in the early years of the waning of Cola imperium. In the generations that followed his, the Cola imperium continued to unwind, as the work of tantric and purānic philology continued and, if anything, intensified. From at least the first part of the thirteenth century, authors composing conventional works of scholarship-works which they claimed as their own, and not as the products of revelation - were necessarily faced with the task of reckoning with this great proliferation of anonymous texts, both those which were the products of their own milieux and works that had been on the syllabus since time out of mind. As legatees of this textual dispensation, scholars were faced with both a spectrum of potential problems - the authenticity of their sources first among them-but also with the possibility of the strategic adoption of the philological tools that their anonymous forebears had used in their own works. The very same methods of textual incorporation and bibliographic organization could be added to the skills that emerged from a classical sanstric education - the deep-seated habit of taxonomic organization, the use of the disputational methods of logic, or the fine-grained skills at textual analysis used in hermeneutics or in literary theory - to produce a new and innovative form of philological scholarship that could hold its own among the traditional knowledge-systems.

The formation of this new, properly 'authorial' style of textual scholarship can be seen by way of the three case studies found in the following chapters. In their reaction to and application of the modes of philology we have been following, we can clearly trace the effects of their reception in these works, and begin to understand the new forms of knowledge and of textuality that this reception enabled. As with Cekkilār, these authors' works cannot be reduced to simply a response to the stimulus afforded by the anonymous philologists: all three operated at the intersection of the new tantric texts and classical śästras of great antiquity and authority. And like Cekkilāar's innovative forging of the 
purānam as a literary mode in Tamil, all three authors were preoccupied by the problem of newness, with the creation of new methods of study and the confection of new hybrid textual genres. 